Asian J. Med. Biol. Res. 2015, 1 (2), 292-296; doi: 10.3329/ajmbr.v1i2.25624

\author{
Asian Journal of \\ Medical and Biological Research \\ ISSN 2411-4472 (Print) 2412-5571 (Online) \\ www.ebupress.com/journal/ajmbr
}

\title{
Article \\ Microbial analysis of raw and pasteurized milk from selected areas of Dinajpur, Bangladesh
}

Md. Amirul Hasan ${ }^{1 *}$, Md. Aminul Islam², Mohammad Showkat Mahmud ${ }^{1}$, A.S.M. Ashab Uddin ${ }^{1}$ and Shamim Ahmed $^{1}$

${ }^{1}$ Bangladesh Livestock Research Institute, Savar, Dhaka-1341, Bangladesh

${ }^{2}$ Department of Microbiology, Hajee Mohammad Danesh Science \& Technology University, Dinajpur, Bangladesh

*Corresponding author: Dr. Md. Amirul Hasan, Scientific Officer, Bangladesh Livestock Research Institute, Savar, Dhaka-1341, Bangladesh. Mobile: +8801712690774; Email: amirulhasan.vet@gmail.com

Received: 26 July 2015/Accepted: 13 September 2015/ Published: 30 September 2015

\begin{abstract}
Milk is highly vulnerable to microbial contamination and consequently is easily perishable. The aim of the present study was microbial analysis of raw and pasteurized milk. For this, a total of 32 milk samples (12 from raw milk and 20 from pasteurized milk) were collected from 8 sources. Among them three were raw (R1 to R3) sources and rest five were pasteurized milk (P1 to P5) sources. Each of the collected samples was investigated during the period from May to December, 2012. All milk samples were subjected to total viable count (TVC), total coliform count (TCC), Total Staphylococcus count (TSC) and Gram's staining to determine the loads of microbes in raw and pasteurized milk. Total viable counts (TVC) range of 12 raw milk samples (R, R2 and R3) were $1.3 \times 10^{6}$ to $7.4 \times 10^{5} \mathrm{cfu} / \mathrm{ml}$. The presence of Escherichia coli in the raw milk samples were from $2.3 \times 10^{2}$ to $9.4 \times 10^{2} \mathrm{cfu} / \mathrm{ml}$, but the presence of Staphylococcus were from $5.9 \times 10^{2}$ to $7.9 \times 10^{2} \mathrm{cfu} / \mathrm{ml}$. Whereas, the range of TVC for five brands of pasteurized milk (P1, P2, P3, P4, and P5) were from $1.8 \times 10^{4}$ to $9.8 \times 10^{4} \mathrm{cfu} / \mathrm{ml}$, TSC were from $2.8 \times 10$ to $8.6 \times 10^{2} \mathrm{cfu} / \mathrm{ml}$ and TCC from $1.01 \times 10^{2}$ to $9.1 \times 10 \mathrm{cfu} / \mathrm{ml}$. Therefore, it can be concluded that high counts of bacteria were found in raw milk and pasteurized milk. The government therefore should conduct frequent inspection of the marketed milks to check whether they meet the minimum legal standards and should monitor the overall hygienic condition surrounding the production and handling of milk. Realistic standards for the raw milks need to be devised and appropriate training should be given to the raw milk producers in hygienic handling of milk.
\end{abstract}

Keywords: raw milk; pasteurized milk; microbial quality; TVC

\section{Introduction}

Milk is highly vulnerable to bacterial contamination and hence is easily perishable (Kim et al., 1983; Steele et al., 1997). Milk as well as dairy products are important sources of food borne pathogens and numerous epidemiological reports have implicated inadequate heat treated milk and raw-milk products are the major factors for illnesses caused by food-borne pathogens (De Buyser et al., 2001; Harrington et al., 2002). So it is mandatory this product to be obtained as cleanest possible and not to harm the consumers' health (Dan et al., 2008). The presence of pathogenic bacteria in milk emerged major public health concerns (Ryser, 1998). Many milk borne epidemics of human diseases are spread through consumption of contaminated milk (Parekh and Subhash, 2008). Few examples of the known milk -borne diseases are bovine tuberculosis, brucellosis, anthrax, listeriosis, salmonellosis, leptospirosis, Q fever, campylobacteriosis and E. coli O157:H7as an emerged new milk -borne bacterial pathogen reported recently with a very serious health effects (Sivapalasingams et al., 2004). To protect consumers and public health against these milk -borne infections it require proper hygienic milking and milk handling procedures. 
Common bacteria reported to be isolated from milk include Staphylococcus spp., Listeria spp., Salmonella spp., E. coli, Campylobacter spp., Mycobacterium spp., Brucella spp., Coxiella burnetii, Yersinia spp., Pseudomonas aeroginosa and Corynebacterium ulcerans. Others are Proteus spp., Leptospira spp., Clostridium spp., Streptococcus spp, Klebsiella spp., Enterobacter spp. and Bacillus spp. (Shirima et al., 2003; Sivapalasingams et al., 2004; Al-Tahiri, 2005;

Milk is a perishable product and an ideal medium for the growth of a wide variety of bacteria (Parekh and Subhash, 2008). When it is secreted from a healthy udder, raw milk contains only a very few bacteria of about 500 to 1,000 bacteria per milliliter (Omore et al., 2005; Pandey and Voskuil, 2011). After milking enviromental contamination occurs, which in turns increases the total bacteria count up to 50,000 per $\mathrm{ml}$ or may even reach several millions bacteria per milliliter (Pandey and Voskuil, 2011). That count level indicates a very poor hygienic standard of milk during milking a nd handling or milk of a diseased animal. The presence of coliform bacteria particulary E. coli in raw milk is an indicator of feacal contamination which implies poor hygienic conditions and unsanitized environment since these bacteria are of faecal origin.

In developing countries, most of the milk is produced by mallholder farmers dominated by local herds of cattle (Pandey and Voskuil, 2011). Their milking units are widely distributed throughout in rural areas with a poor infrastructure, while most of the markets and customers are in urban areas. Therefore, the need for good hygienic practices and a streamlined collection, handling and transport system is important but has been always a challenge (Pandey and Voskuil, 2011). However, milk contains a natural inhibitory system or temporary germicidal or bacteriostatic properties which prevents a significant rise in the bacteria count during the first 2 3 hours (Swai and Schoonman, 2011; Pandey and Voskuil, 2011 ). Thus the evaluation of microbial quality in milk is vital. The aim of the present study was conducted to investigate occurrence and microbial load in raw and pasteurized milk and also compare among different brands of pasteurized milk.

\section{Materials and Methods}

\subsection{Study area}

The study was conducted during the period from May to December, 2012. The milk samples were collected from different retail markets and farm house of Dinajpur area, Bangladesh.

\subsection{Collection of sample}

A total of 32 milk samples were collected from 8 sources. 12 raw milk samples from three sources (designated as R1 to R3) of local dairy farm, remaining 20 samples from five (P1 to P5) sources of different commercial packaged pasteurized milk were selected for this study. Aseptic techniques were strictly maintained during sample collection. Raw milk samples were collected in sterile glass bottle and packaged pasteurized milk were in sterial containers which were kept cool in ice boxes and immediately transported to the microbiology laboratory of Hajee Mohammad Danesh Science and Technology University, Bangladesh.

\subsection{Sample processing and isolation of microbes}

Prior to taking samples, milk containing bottle and packet were held firmly and shaken thoroughly for proper mixing of the milk samples. To get milk the packed was cut open with the help of sterile scissors. The cut is so made obliquely at one of the corners that there is sufficient opening for the sterile pipette to enter easily into the pasteurized milk inside. To obtain countable plate with individual colonies the samples were diluted using simple 1/10 dilutions. For a 1/10 dilution 1 part sample was added to 9 parts diluents (Distilled water) then mixed thoroughly. A series of dilutions was made as desired, and from one or more of these dilutions, known amounts were inoculated in an agar by pour plate techniques.

\subsection{Identification of microbes}

The forgoing prepared milk samples were bacteriologically examined in order to determine the total viable count (TVC), total coliform count (TCC), and total Staphyloccus count (TSC) on plate count agar (PCA), MacConkey agar (MCA) and Staphylococcus agar no-110 media, respectively. Plates exhibiting colonies were counted. The average number of colonies in a particular dilution was multiplied by the dilution factor to obtain the total count. The total count was expressed as the number of organism of colony forming units per $\mathrm{ml}$ (CFU/ml) of samples according to ISO (1995). All the data obtained during the study were analyzed statistically. 


\subsection{Statistical analysis}

Data on the total viable count, coliform and staphylococcal count $/ \mathrm{ml}$ of collecting sample from each point were subjected to Chi-Square Test using Microsoft Excel 2007 program. Significant differences of the data were established by least significant difference at the $5 \%$ level of significance.

\section{Results}

A total of 32 liquid milk samples, 12 raw milk samples from dairy farm, chilling center and local market denoted as R1, R2 and R3, respectively with 4 in each case and rest 20 pasteurized milk samples from different shops under specific brand name denoted as P1, P2, P3, P4 and P5 with 4 in each case too, were collected. The liquid milk samples were subjected to bacteriology laboratory of Hajee Mohammad Danesh Science and Technology University (HSTU) to determine the microbial load. The results of bacterial distribution in the collected samples are as follows.

\subsection{Total viable count (TVC)}

Total Viable Count (TVC) of bacteria was carried out on plate count agar media using pour plate techniques. The results, presented in Table 1, showed that the average TVC $(\mathrm{cfu} / \mathrm{ml})$ were $7.4 \times 10^{5}(\log 5.87), 1.3 \times 10^{6}(\log$ 6.13) and $1.9 \times 10^{6}(\log 6.29)$ for raw milks collected from different sources, R1, R2 and R3, respectively. The counts for pasteurized milk samples, P1, P2, P3, P4 and P5 were $9.8 \times 10^{4}(\log 4.99), 6.8 \times 10^{4}(\log 4.83), 1.9$ $\mathrm{x} 10^{5}(\log 5.29), 1.8 \times 10^{4}(\log 4.27)$ and $5.3 \times 10^{4}(\log 4.72)$, respectively.

\subsection{Total coliform count (TCC)}

The average measures of TCC $(\mathrm{cfu} / \mathrm{ml})$ of milk samples were $2.3 \times 10^{2}(\log 2.37), 2.6 \times 10^{2}(\log 2.42)$ and 9.4 $\mathrm{x} 10^{2}(\log 2.97)$ for raw milks collected from different sources, R1, R2 and R3, respectively (Table 1). The results for pasteurized brand milks, P1, P2, P3, P4 and P5 were $1.6 \times 10^{2}(\log 2.21), 9.1 \times 10(\log 1.9), 3.4 \times 10^{2}$ $(\log 2.54), 0$ and $1.01 \times 10^{2}(\log 2.00)$.

\subsection{Total staphylococcal count (TSC)}

Staphylococcus agar no-110 medium was used for the enumeration of total staphylococcal count (TSC) in the milk samples. In the raw milks the TSC $(\mathrm{cfu} / \mathrm{ml})$ were $7.9 \times 10^{2}(\log 2.90), 5.9 \times 10^{2}(\log 2.77)$ and $6.1 \times 10^{2}(\log$ 2.78) for R1, R2 and R3, respectively. The values of TSC ( $\mathrm{cfu} / \mathrm{ml})$ of pasteurized milks were $8.6 \times 10^{2}(\log$ 2.93), $6.4 \times 10^{2}(\log 2.81), 4.4 \times 10^{2}(\log 2.64), 8.5 \times 10^{2}(\log 2.93)$ and $2.8 \times 10^{1}(\log 1.44)$ for P1, P2, P3, P4 and $\mathrm{P} 5$, respectively.

\subsection{Microscopic examination}

In Gram's staining under microscope, smears from plate count agar, MacConkey agar and Staphylococcus agar no-110 Medium were examined. In case of PCA, there were presence of both Gram's positive and Gram's negative organisms with different arrangements. From MCA, Gram's negative, pink color, mostly rood shape organisms were revealed. For Staphylococcus agar no-110, Gram's positive, violet color, short cocco-bacilli or rod were found within bundles and singly arranged.

Table 1. The average counts of TVC, TCC and TSC in raw and different brands of pasteurized milk.

\begin{tabular}{clllllll}
\hline $\begin{array}{l}\text { Sources } \\
\text { of Milks }\end{array}$ & $\begin{array}{l}\text { Numbers } \\
\text { of Tested } \\
\text { Sample }\end{array}$ & \multicolumn{2}{c}{ Total Viable Count/ml } \\
& cfu/ml & Log10 & \multicolumn{2}{c}{$\begin{array}{c}\text { Total Coliform } \\
\text { Count/ml } \\
\text { cfu/ml }\end{array}$} & \multicolumn{2}{c}{$\begin{array}{c}\text { Total Staphylococcus } \\
\text { count/ml }\end{array}$} & cfu/ml \\
Log10
\end{tabular}




\section{Discussion}

The investigation on microbial analysis of raw and different brands of pasteurized milk was conducted to evaluate milk samples obtained from two important sources viz., raw and pasteurized milk. PCA, MCA and Staphyloccocus agar no-110 were used for the enumeration of bacteria from milk in agreement with other workers (Mhone et al., 2011; Hossain et al., 2010). The study revealed that the total viable counts (TVC) for raw milk were ranges from Total viable counts (TVC) range of 12 raw milk samples (R1, R2 and R3) were 1.3 x $10^{6}$ to $7.4 \times 10^{5} \mathrm{cfu} / \mathrm{ml}$. The presence of Escherichia coli in the raw milk samples were from $2.3 \times 10^{2}$ to 9.4 $\times 10^{2} \mathrm{cfu} / \mathrm{ml}$, but the presence of Staphylococcus were from $5.9 \times 10^{2}$ to $7.9 \times 10^{2} \mathrm{cfu} / \mathrm{ml}$. Whereas, the range of TVC for five brands of pasteurized milk (P1, P2, P3, P4, and P5) were from $1.8 \times 10^{4}$ to $9.8 \times 10^{4} \mathrm{cfu} / \mathrm{ml}$, TSC were from $2.8 \times 10$ to $8.6 \times 10^{2} \mathrm{cfu} / \mathrm{ml}$ and TCC from $1.01 \times 10^{2}$ to $9.1 \times 10 \mathrm{cfu} / \mathrm{ml}$., with an average of 1358333 $\mathrm{cfu} / \mathrm{ml}$ which is corresponding to the findings of Dan (2008). The average count ( $\mathrm{cfu} / \mathrm{ml})$ for pasteurized milk was observed in samples belong to P1-9.8 x10 (log 4.99), P2-6.8 $\times 10^{4}(\log 4.83)$, P3-1.9 x10 $(\log 5.29), \mathrm{P} 4-1.8$ $\mathrm{x} 10^{4}(\log 4.27)$ and P5-5.3 x10 $(\log 4.72)$. It was evident from the result that the average TVC count was nearly matched to Lingathorni (2009). Average counts for E. coli in raw milk samples were $481 \mathrm{cfu} / \mathrm{ml}$ where as in pasteurized milk $E$. coli counts for P-1,P-2,P-3,P-4, P-5 were $1.6 \times 10^{2} \mathrm{cfu} / \mathrm{ml}(\log 2.21), 9.1 \times 10(\log 1.9)$ $\mathrm{cfu} / \mathrm{ml}, 3.4 \times 10^{2} \mathrm{cfu} / \mathrm{ml}(\log 2.54), 0$ and $1.01 \times 10^{2} \mathrm{cfu} / \mathrm{ml}(\log 2.00)$, respectively. Total Staphylococcal count in the raw milks ranged from $5.9 \times 10^{2}$ to $7.9 \times 10^{2} \mathrm{cfu} / \mathrm{ml}$. These counts were less than the findings of Ghose and Maharajan (2002) where the mean Staphylococcal counts were $4.7 \times 10^{6} \mathrm{cfu} / \mathrm{ml}$ in raw milk but higher than that of Srairi et al. (2006) where TSC ranged from $<30 \mathrm{cfu} / \mathrm{ml}$. In contrast to different recommended standard for milk foods, sanitary condition of milks sample used for this study were not satisfactory. United State standards recommended, each $\mathrm{ml}$ of raw milk for pasteurization must have less than $3 \times 10^{5} \mathrm{cfu} / \mathrm{ml}$ (Coast et al., 2004; Heinemann et al., 1999). Unfortunately, the results of TVC ranged from $1.3 \times 10^{6}$ to $7.4 \times 10^{5} \mathrm{cfu} / \mathrm{ml}$ is almost far greater than the United State standard. The bacteria count in the pasteurized milk samples ranged from 1.8 $\mathrm{x} 10^{4}$ to $9.8 \times 10^{4} \mathrm{cfu} / \mathrm{ml}$, much higher than that recommended by BSTI and USPHS, i.e., not exceeding 20,000 $\mathrm{cfu} / \mathrm{ml}$ (BSTI, 2002; Jay, 2003). The reason for high bacteria count in the pasteurized milks may include defective pasteurization machinery, survival of pasteurization and post-pasteurized contamination such as poor processing and handling conditions and/or poor worker hygiene. Coliforms are considered as indicator organisms because their presence in food indicates some form of contamination. The coliforms standards for Grade 'A' pasteurized milk and milk products should not be over 10/ml (BSTI, 2000) and for certified pasteurized milk should not be over $1 / \mathrm{ml}$. The present investigation however reported significantly high coliforms count than that recommended by BSTI (2002). E. coli causes severe diarrhea in newborns and adolescents and originates from mastitis (Kornalijnslijper et al., 2004). However, the raw and pasteurized milk of this study are not only top grade but also some kinds of them are unusable. In consideration of comparative figure of microbial load in the best quality raw milk to different brands of Pasteurized milk, all pasteurized milk contained lower TVC count. For TCC the P-3 brands pasteurized milk contain higher count than the best quality raw milk. In case of Staphylococcus count surprisingly P-1, P-2, P-4 contain high bacteria count than raw milk sample.

\section{Conclusions}

It was concluded from the study that microbial loads of raw milk were not satisfactory. Therefore, it could be assume that the handler of raw milk do not maintain good personal hygiene. All most all brands of pasteurized milk tested in this study were of low quality based on BSTI standard. Presence of E. coli and Staphylococcus spp. were of public health concern. Government therefore should conduct frequent inspection of the marketed milks to check whether they meet the minimum legal standards and should monitor the overall hygienic condition surrounding the production and handling of milk. Realistic standards for the raw milks need to be revised and appropriate training should be given to the raw milk producers in hygienic handling of milk.

\section{Conflict of interest}

None to declare.

\section{References}

Al-Tahiri R, 2005. A comparison on microbial conditions between traditional dairy products sold in Karak and same products produced by modern dairies. Pak. J. Nutri., 4: 345-348 
BSTI, 2002. Bangladesh Standards and Testing Institution,Tejgaon, Dhaka. Bangladesh Standard: Specification for Pasteurized Milk, pp. 2-3.

Dan SD, M Mihaiu, O Rotaru and I Delea, 2008. Evaluation of microbiological load and configuration of raw milk from collecting Centers in Cluj County. Buletin USAMV Vet. Med., 40: 258-265.

Buyser D, B Dufour, M Maire and V Lafarge, 2001. Implication of milk and milk products in food-borne disease in France and different industrialized countries. Int. J. Food Micro., 67: 1-17.

Ghose AK, and KL Maharajan, 2002. Milk Marketing Channels in Bangladesh: A case study of three villages from 3 districts. J. Int. Dev. Cooperat., 8: 87-101.

Harrington P, J Archer, JP Davis, DR Croft and JK Varma, 2002. Outbreak of Campylobacter jejuni infections associated with drinking unpasteurized milk through a cow-leasing program-Wisconsin. 51: 548-549.

Heinemann PG, 1919. Milk. W.B. Saunders Co., Philadelphia, : 674.

Hossain TJ, MK Alam and D Sikdar, 2010. Chemical and Microbiological Quality Assessment of Raw and Processed Liquid Market Milks of Bangladesh. Research J. Dairy Sci., 4: 28-34.

Kim HJ, G Hardy, JP Novak, Ramet and F Weber, 1983. Off-tastes in raw and reconstituted milk. FAO Animal, 11: 198-205.

Lingathurai S, P Vellathurail, S Ezil Vendan and PAA Alwin, 2009. A comparative study on the microbiological and chemical composition of cow milk from different locations in Madurai, Tamil Nadu. Ind. J. Sci. Tech., 2: 846.

Mhone TA, G Matope and PT Saidi, 2011. Aerobic bacterial, coliform, Escherichia coli and Staphylococcus aureus counts of raw and processed milk from selected smallholder dairy farms of Zimbabwe. Int. J. Food Microbiol., 151: 223-228.

Omore A, T Lore, S Staal, J Kutwa, R Ouma, S Arimi and E Kang'ethe, 2005. Addressing the public health and quality concerns towards marketed milk in Kenya. Smallholder Dairy Project Research and Development, Report 3. ISBN 92-9146-168-7.

Pandey GS and GCS Voskuil, 2011. Manual on Milk safety, quality and hygiene . Golden Valley agricultural Research Trust, Zambia, p. 52.

Parekh TS, and R Subhash, 2008. Molecular and bacteriological examination of milk from different milch animals with special reference to Coliforms. Curr. Res. Bact., 1: 56-63.

Shirima GM, J Fitzpatrick, S Cleaveland, DM Kambarage, RR Kazwala, J Kunda and NP French, 2003. Participatory survey on zoonotic diseases affecting livestock keeping communities in Tanzania. J. Ani. Vet. Adv., 2: 253 -258

Sivapalasingams S, CR Friedman, L Cohen and RV Tauxe, 2004. Fresh produce: a growing cause of outbreaks of foodborne illness in the United States. J. Food Prot., 67:2342-2353.

Srairi MT, J Moudnib, L Rahho and A Hamama, 2006. How do milking conditions affect the hygienic quality of raw milk? Case study from Moroccan dairy farms. Livestock Res. Rural Dev., Vol. 18.

Steele ML, WB Mcnab, C Poppe, MW Graffiths, S Chen, SA Degrandis, LC Fruhner, CA Larkin, JA Lynch and JA Odumeru, 1997. Survey of Ontario bulk tank milk for food borne pathogens. J. Food Prot., 60: 1341-1346.

Swai ES and L Schoonman, 2011. Microbial quality and associated health risks of raw milk marketed in the Tanga region of Tanzania. Asian Pac. J. Trop. Biomed.,1: 217-222. 